\title{
Molecular Analysis of Hepatitis B Virus Reverse Transcriptase Domain for Mutations Associated with Viral Resistance in Pakistani Patients
}

\author{
Pakistanlı Hastalarda Viral Dirençle llișkili Mutasyonlar Için Hepatit B Virüsü Ters \\ Transkriptaz Domaininin Moleküler Analizi
}

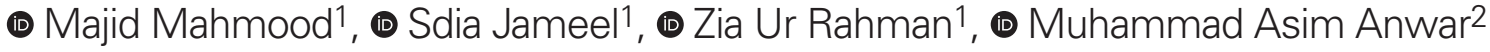 \\ 1 University of Poonch Rawalakot, Department of Zoology, Rawalakot, AJK, Pakistan \\ 2Pakistan Atomic Energy Commission (PAEC) General Hospital, Department of General Medicine, Islamabad, Pakistan
}

\begin{abstract}
Objectives: Current study was designed to screen out the resistant mutations in reverse transcriptase (RT) domain of hepatitis B virus (HBV) genome from non-responder Pakistani patients.

Materials and Methods: A total of 22 patients, receiving different nucleot(s)ide analogues were included in the study. RT domain of the virus from samples of non-responder patients was amplified and sequenced. Sequences were aligned and analyzed for RT domain mutations.

Results: After 18 months, 18 patients were responder and 4 were non-responder. Mean alanine aminotransferase (ALT) and viral load of responder patients decreased significantly as compared to those of non-responder patients. Two of the 4 samples from nonresponders were successfully sequenced. Mutations rtY135S, rtl169P, rtV173P, rtL180I, rtA181V, rtT184Y and rtM204V were identified from the sample of patient 1, while rtL80V/rtL80G and rtY135S were identified from the sample of patient 2.

Conclusion: Mutations rtY135S, rtl169P, rtV173P, rtL180I, rtA181V, rtT184Y, rtM204V, rtL80V/rtL80G, and rtY135S are present in genome of HBV circulating in Pakistani patients. These mutations give resistance to virus against lamivudine, telbivudine, adefovir, and partially resistance against entecavir. However, no mutation was found to be associated with the viral resistance against tenofovir.

Keywords: Hepatitis B virus, RT domain, resistant mutations, nucleot(s)ide analogues, HBV genome
\end{abstract}

\section{ÖZ}

Amaç: Mevcut çalışma, yanıtsız Pakistanlı hastalardan hepatit B virüsü (HBV) genomunun ters transkriptaz (RT) domainindeki dirençli mutasyonları taramak için tasarlanmıştır.

Gereç ve Yöntemler: Çalışmaya farklı nükleot(z)id analogları alan toplam 22 hasta dahil edildi. On sekiz ay sonra, 18 hasta yanıt verdi ve 4 hasta yanıt vermedi. Yanıt vermeyen hastaların örneklerinden alınan virüsün RT domaini amplifiye edildi ve dizilendi. Diziler hizalandı ve RT domaini mutasyonları açısından analiz edildi.

Bulgular: Yanıt veren hastaların ortalama alanin aminotransferaz (ALT) ve viral yükü, yanıt vermeyen hastalarla karşılaştırıldığında önemli ölçüde azaldı. Yanıt vermeyen hastalardan alınan 4 örnekten 2'si başarıyla sıralandı. Birinci hastanın örneğinden rtY135S, rtl169P, rtV173P, rtL180I, rtA181V, rtT184Y ve rtM204V mutasyonları belirlenirken ikinci hastanın örneğinden rtL80V/rtL80G ve rtY135S mutasyonları belirlendi.

Sonuç: Pakistanlı hastalarda saptanan HBV genomunda rtY135S, rtl169P, rtV173P, rtL180I, rtA181V, rtT184Y, rtM204V, rtL80V/ rtL80G ve rtY135S mutasyonları mevcuttu. Bu mutasyonlar, virüse lamivudin, telbivudin ve adefovire karşı tam, entecavire karşı kısmen direnç sağlamaktaydı. Bununla birlikte, tenofovire karşı viral dirençle ilișkili hiçbir mutasyon bulunmadı.

Anahtar Kelimeler: Hepatit B virüsü, RT alanı, dirençli mutasyonlar, nükleot(z)id analogları, HBV genomu

\footnotetext{
Mahmood M, Jameel S, Ur Rahman Z, Anwar MA. Molecular Analysis of Hepatitis B Virus Reverse Transcriptase Domain for Mutations Associated with Viral Resistance in Pakistani Patients. Viral Hepat J. 2021;27:153-158.
} 


\section{Introduction}

Hepatitis B virus (HBV), a member of hepadnaviridae family of viruses, is a pathogen of human hepatocytes first recognized in 1960s $(1,2)$. The undesirable effects caused by HBV infection include liver degeneration, liver cirrhosis, hepatocellular carcinoma, and liver failure (3). Approximately 257 million people are chronic carriers of HBV in the world. The annual number of deaths caused by HBV related infections were estimated to be 887000 in 2015 (4). However, the infection rate of HBV has been decreased significantly in developed countries $(5,6)$ but there is no such report from developing and underdeveloped countries, including Pakistan.

Interferon- and nucleot(s)ide analogues (NAs) are clinically available treatments for HBV. Interferon reduces the hepatitis B surface antigen level from blood alongside immunomodulatory effects but it poses many adverse side effects (7). NAs treatment is easier in use than interferon therapy, though it also has some side effects but fewer (8). Five nucleotide/nucleoside analogues are so far used for treatment of chronic HBV Infection. These are: lamivudine, adefovir dipivoxil, entecavir, telbivudine, and tenofovir disoproxil fumarate. All of these act on the reverse transcriptase (RT) region of the viral genome stopping the production of DNA from pre-genomic RNA $(8,9,10)$.

HBV replication is an error prone process because it has no proofreading activity, leading to high mutation rate in the genome $(11,12)$. Some of these mutations may cause viral resistance against treatment and this antiviral resistance is the greatest stumbling block in HBV treatment (13). Several mutations in the RT domain are considered to be associated with resistance to nucleotide or nucleoside analogues in the treatment of chronic HBV $(3,6,14)$. However, all the mutations occurring in HBV polymerase region are not associated with resistance. A few are well known mutations associated with primary drug resistance to NAs, which are: rtL80G/l, rtl169T/P, rtV173L, rtL180M/l, rtA181TN/S, rtT184S, rtS202I/G/S, rtM204V/S/l, rtN236T, rtN238D/S/R and rtM250V/I/L.

The objective of current study was to screen out the nonresponder patients for resistance mutations in RT domain of HBV from non-responder patients, and to compare some factors of nonresponders with responder patients.

\section{Materials and Methods}

This was a cross sectional study conducted during August 2020 to March 2021. The surveys were conducted in hospitals to select the patients receiving different nucleotide analogues. A total of 22 chronic HBV patients who completed at least 18 months of NAs treatment were selected with the help of a gastroenterologist. A performa was filled for each patient, which included all the treatment history and other important information. A written informed consent was given to each of the patient and the patients keen to contribute in the study were enrolled. The patients with a positive treatment response were also monitored for breakthrough. Blood samples were collected from all the non-responder patients (Figure 1).

\section{Pre-treatment Factors}

Pre-treatment viral factors like genotype, hepatitis B e antigen, and viral load were recorded for all patients before and on every 6 months of treatment. Different host factors like age, gender, body
Total HBV patients recieving NAs 22

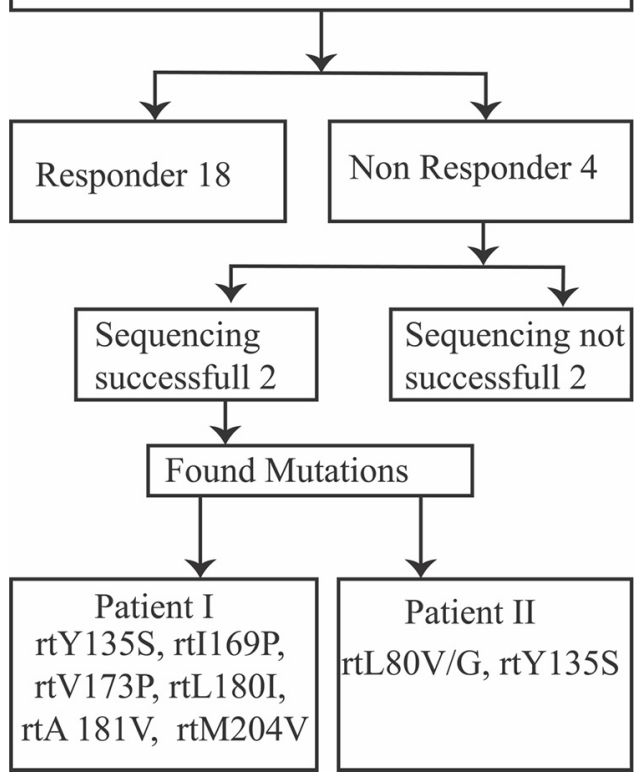

Figure 1. Flow chart of complete study including patients' selection and main findings

HBV: Hepatitis B virus, NAs: Nucleot(s)ide analogues

weight, alanine aminotransferase (ALT), dental procedure, previous surgery record, infection age, and previous treatment, history were also recorded.

\section{DNA Extraction and Amplification}

Viral DNA was extracted using commercially available kits and a fragment of genome including RT domain was amplified by polymerase chain reaction using previously described primers $(15,16)$. PCR conditions were optimized in a gradient PCR machine and the quantitative measurement of viral load was achieved by a real time PCR machine.

\section{Products Purification}

The amplified DNA fragments were purified for sequencing using ethanol precipitation kit protocol (Beckman Coulter, USA).

\section{Sequencing}

Sequencing of the purified DNA fragments of RT domain was obtained commercially by sending the DNA to commercial service providers where the sequencing was performed by chain termination method. The sequencing instrument used was "CEO $8000 \mathrm{XL}$ " analysis system for the sequencing reaction.

\section{Statistical Analysis}

The sequences were aligned with wild type HBV sequences and analyzed for resistant mutations in the RT domain. Manual analyses of sequences were also carried out. The mutations were also confirmed by "geno to pheno HBV", the online data base for HBV genome analysis.

\section{Ethical Approval}

The study was started after the approval from "humans and animals ethics committee", University of Poonch Rawalakot. An 
informed consent was given to each of the patient for reading and signing before his/her enrolment to the study.

\section{Results}

\section{Patients and Treatment Details}

During the study period, 22 hepatitis B patients receiving treatment were enrolled at Pakistan Atomic Energy Commission General Hospital Islamabad. Out of the 22 enrolled patients, 18 (81.8\%) showed response during treatment while 4 (18.2\%) did not show any response to treatment and considered nonresponder after 18 months of treatment (Figure 1). The mean age of responder patients was calculated to be $36.45 \pm 14.89$ years while the mean age of non-responder patients was calculated to be $38.50 \pm 13.63$ years. No significant difference $(p=0.660)$ of mean age between responder and non-responder patients was found (Table 1).

In total, 12 patients were male and 10 were female. Out of the four non-responder patients, 2 were male and 2 were female while 10 of the 18 responder patients were male and eight were female (Table 1).

\section{Viral Load Comparison}

The mean pre-treatment viral load of responder patients was found to be $7.24 \mathrm{E} 7 \pm 3.56 \mathrm{E} 5$ while the mean pre-treatment viral load of non-responder patients was $7.13 E 7 \pm 2.32 E 3$. There was no significant difference $(p=0.183)$ of mean viral load between responder and non-responder patients before the treatment (Table 1).

After 6 months of treatment, the viral load of responder patients was significantly lower as compared to the viral load of non-responder patients $(p=0.009)$. At this stage, the mean viral load of responder patients was calculated to be 9.74E4 $\pm 3.46 \mathrm{E} 5$ while the mean viral load of non-responder patients after 6 months of treatment was $9.02 \mathrm{E} 7 \pm 2.42 \mathrm{E} 3$ (Table 1).

The mean viral load of responder patients after 12 months of treatment was 7.57E3 $\pm 3.27 \mathrm{E} 4$ while the mean viral load of nonresponder patients after 12 months was $3.96 \mathrm{E} 5 \pm 1.48 \mathrm{E} 3$ (Table 1) and the difference was again significant statistically $(p=0.021)$.

After 18 months of treatment, the responder patients had undetectable or very low viral load in serum but the non-responder patients still had a mean viral load of $4.63 E 5 \pm 6441$ copies $/ \mathrm{mL}$ (Table 1).

\section{ALT}

The mean pre-treatment ALT of responder patients was found to be $53.90 \pm 31.16$ while mean ALT of non-responder was $55.11 \pm 14.51$. There was no significant difference $(p=0.697)$ of mean ALT between responder and non-responder patients before treatment (Table 1).

The mean ALT of responder patients after six months of treatment was $41.35 \pm 20.51$ while mean ALT of non-responder patients after six months was $47.61 \pm 9.27$. There was no significant difference $(p=0.705)$ of mean ALT between responder and nonresponders (Table 1 ).

After 12 months of treatment, the mean ALT of responder patients was $30.55 \pm 8.34$ while mean ALT of non-responder after twelve months was $44.61 \pm 8.13$. There was significant difference ( $p=0.001)$ of mean ALT between responder and non-responder after 12 months of treatment (Table 1).

The mean ALT of responder patients after 18 months of treatment was $26.50 \pm 4.12$. While mean ALT of non-responder after eighteen months was $43.83 \pm 8.06$. There was significant difference $(p=0.000)$ of mean ALT between responder and nonresponder patients after 18 months of treatment (Table 1).

\section{Mutational Analysis}

The blood samples of all 4 non-responder patients were sent for sequencing but unfortunately, DNA of two samples was not successfully sequenced while the remaining two samples were sequenced successfully. RT mutations, well known for their role in resistance, were found in both of these samples.

\section{Mutational Profile of Patient 1}

Patient 1 was male of 49 years who received lamivudine and entecavir treatments. The RT domain of the virus isolated from this patient was detected with rtY135S, rtl169P, rtV173P, rtL180I, rtA181V, rtT184Y and rtM204V mutations. These mutations are known to be associated with viral resistance against lamivudine telbivudine adefovir and entecavir. The patient was non-responder against lamivudine due to compensatory mutations rtL180I,

Table 1. Comparison of responder and non-responder patients in the study

\begin{tabular}{|c|c|c|c|c|}
\hline \multicolumn{2}{|l|}{ Factor } & Responder & Non-responder & Sig. \\
\hline \multicolumn{2}{|l|}{ Age } & $36.45 \pm 14.89$ & $38.50 \pm 13.63$ & 0.662 \\
\hline Gender & Male & $10(83.3 \%)$ & $2(16.7 \%)$ & 0.377 \\
\hline \multirow{2}{*}{ Viral load } & Pre treatment & $7.24 \mathrm{E} 7 \pm 3.56 \mathrm{E} 5$ & $7.13 \mathrm{E} 7 \pm 2.32 \mathrm{E} 3$ & 0.183 \\
\hline & After 6 months & $9.74 \mathrm{E} 4 \pm 3.46 \mathrm{E} 5$ & $9.02 \mathrm{E} 7 \pm 2.42 \mathrm{E} 3$ & 0.009 \\
\hline \multirow{4}{*}{ ALT } & Pre treatment & $53.90 \pm 31.16$ & $55.11 \pm 14.51$ & 0.697 \\
\hline & After 6 months & $41.35 \pm 20.51$ & $47.61 \pm 9.27$ & 0.705 \\
\hline & After 12 month & $30.55 \pm 8.34$ & $44.61 \pm 8.13$ & 0.001 \\
\hline & After 18 month & $26.50 \pm 4.12$ & $43.83 \pm 8.06$ & 0.000 \\
\hline
\end{tabular}


rtV173P, rtL180I and rtM204V, while it was non-responder against entecavir due to rtM204V, rtl169P, rtT184Y and rtL180V (Table 2).

\section{Mutational Profile of Patient 2}

Patient 2 was a female of 41 years who was treated with lamivudine for 18 months. According to resistance profile, the patient was resistant against lamivudine due to compensatory mutations rtL80V/rtL80G and rtY135S. This mutational profile shows that the patient is not resistant against adefovir, entecavir, and tenofovir (Table 2).

\section{Discussion}

The quantitative factors like viral load and ALT significantly decreased during treatment in responder patients while not in nonresponders. However, the sample size of the study was low and not enough for comparative analysis of quantitative factors. So, the study was designed to detect the RT mutations responsible for resistance instead of quantitative comparison.

In this study the resistant mutations rtY135S, rtV173P, rtL180I, rtM204V, rtA181V, rtl169P, and rtT184Y were detected which made the patients non-responder against lamivudine, telbivudine, adefovir and entecavir. However, no mutation was found in association with tenofovir.

In a similar type of previous study from Pakistan, almost same mutations were detected from multiple drug resistant patients (16). The mutations reported in that study were: rtL80G, rtY135S, rtl169P, rtV173L, rtL180M, rtA181V, rtT184Y, rtM204V and rtN248H, which were reported to be associated with lamivudine, telbivudine, adefovir and entecavir. Mutation rtN248H was not found in current study, however it was reported in the only previous study from Pakistan. Mutation rtY135S was found in current study which was only reported in the other study from Pakistan (16). It was reported previously from Pakistan that resistance mutations are found frequently on the positions rtL80V/G, rtY135S, rt169P and rt248H while present in low proportion on positions rt184Y and rtL80G.

Another recent study from Iraq reported the mutations rtL80IN, rtV173L, rtL180M, rtA181S, rtA194T, rtS202I, rtM204V/l, rtN236T and rtM250LN associated with resistance against lamivudine, telbivudine, adefovir, entecavir and tenofovir (17). However, the mutations rtA194T, rtN236T, and rtM250LN were not found in our study. Mutation on position rtA194T was generally considered as associated with tenofovir resistance.

The mutations rtM204l and rtL180M, detected in our study, were most frequently found in previous studies from different areas of the world $(2,3,16,17,18,19,20,21,22,23,24,25,26,27,28,29,30,3$ $1,32,33,34,35,36,37,38,39,40,41,42)$. In many of the studies $(7,9$, $16,17,20,22,24,25,26,27,28,29,32,39,40,41)$, these two mutations were reported to have an association with lamivudine while in some other studies $(7,9,16,17,31,32,35,37)$, these were found to be associated with telbivudine resistance as well. These reports confirm that the mutations rtM204I and rtL180M have association with lamivudine and telbivudine resistance. Besides telbivudine and lamivudine resistance, these mutations were also reported to have some association with other NAs like adefovir, entecavir and tenofovir $(2,3,18,19,23,30,33,38,42)$.

The mutations rtV173P and rtL80G, detected in our study, were second most frequent mutations reported in previous studies $(2,9,16,17,18,19,26,29,37,43,44)$. In some studies $(9,16,17,26,29,37,43,44)$, rtV173P was reported to have an association with lamivudine while in some other studies $(9,16,17,37,43)$, it was found to be associated with telbivudine. In some studies $(16,17,26,37,43)$, the mutation rtL80G was reported to have an association with lamivudine and telbivudine resistance. These reports confirm that the mutations rtV173P and rtL180M have association with lamivudine and telbivudine resistance. In some studies $(2,18,19)$, rtV173P was reported to have association to other NAs too.

The mutations rtA181V detected in our study was third most frequent mutation reported in previous studies $(7,9,16,17,33,34,37,38,40,41)$. In all studies, rtA181V was reported to have an association with adefovir resistance while it was reported to cause multiple drug resistance in some studies too. This mutation was also detected in our study from a non-responder patient.

The mutations rtl169P and rtT184Y detected in our study were fourth most frequent mutations reported previously $(16,19,29,33,35,39,40)$. In some studies $(16,19,29,39,40)$, rtT184Y was found to be associated with entecavir resistance while in some other studies, these mutations were shown to have an association with adefovir and lamivudine resistance too $(33,35)$. In three studies, mutation rtl169P was reported to be associated with entecavir resistance too $(16,19,29)$.

In Pakistan, the mutational analysis is not performed before the start of therapy which increases the risk of treatment failure in chronic HBV patients. It is mainly due to lack of facility and lack of awareness. Another fact behind the unavailability of mutation testing is the unavailability of experts who can carry out the mutational screening. Present study confirms that the resistance

Table 2. Resistance mutations profile of the non-responder patients in the study

\begin{tabular}{|c|c|c|c|c|}
\hline & \multicolumn{2}{|l|}{ Patient 1} & \multicolumn{2}{|l|}{ Patient 2} \\
\hline & Detected mutations & $\begin{array}{l}\text { Resistance } \\
\text { prediction }\end{array}$ & Detected mutations & $\begin{array}{l}\text { Resistance } \\
\text { prediction }\end{array}$ \\
\hline Adefovir associated & rtA181V & Resistant & None & Susceptible \\
\hline Telbivudine associated & rtl169P, rtT184Y & Resistant & $\mathrm{rtl} / 80 \mathrm{~V}, \mathrm{rtL} 80 \mathrm{G}$ & Resistant \\
\hline Tenofovir associated & None & Susceptible & None & Susceptible \\
\hline
\end{tabular}


mutations are present in the genomes of viruses circulating in the country. So, it is necessary to analyze the RT domain of virus before start of therapy in the patients.

\section{Study Limitations}

The study has a small number of non-responder patients that is a limitation of current study.

\section{Conclusion}

Mutations rtY135S, rtl169P, rtV173P, rtL180I, rtA181V, rtT184Y, rtM204V, rtL80V/rtL80G, and rtY135S are present in genome of $\mathrm{HBV}$ circulating in Pakistani patients. These mutations give resistance to virus against lamivudine, telbivudine, adefovir, and partially resistance against entecavir. However, no mutation was found to be associated with viral resistance against tenofovir

\section{Ethics}

Ethics Committee Approval: The study was started after the approval from "humans and animals ethics committee", University of Poonch Rawalakot.

Informed Consent: An informed consent was given to each of the patient for reading and signing before his/her enrolment to the study.

Peer-review: Externally peer-reviewed.

\section{Authorship Contributions:}

Concept: M.M. Design: M.M., M.A.A., Data Collection or Processing: S.J., Z.U.R., M.A.A., Analysis or Interpretation: M.M., S.J. Literature Search: S.J., Z.U.R. Writing: M.M., S.J., Z.U.R.

Conflict of Interest: No conflict of interest was declared by the authors.

Financial disclosure: The authors declare no financial support.

\section{References}

1. Ganem D, Prince AM. Mechanisms of disease hepatitis B virus infection natural history and clinical consequences. New Eng $\mathrm{J}$ Med. 2004;350:1118-1200.

2. Yamada N, Sugiyama R, Nitta S, Murayama A, Kobayashi M, Okuse C, Suzuki M, Yasuda K, Yotsuyanagi H, Moriya K, Koike K, Wakita $\mathrm{T}$, Kato T. Resistance mutations of hepatitis $\mathrm{b}$ virus in entecavirrefractory patients. Hepatol Commun. 2017;1:110-122.

3. Choe WH, Kim K, Lee S, Choi Y, Kwon SY, Kim JH, Kim BJ. Tenofovir is a more suitable treatment than entecavir for chronic hepatitis $B$ patients carrying naturally occurring rtM204l mutations. World $\mathrm{J}$ Gastroenterol. 2019;25:4985-4998.

4. Tan M, Bhadoria AS, Cui F, Tan A, Holten JV, Easterbrook P, Ford $\mathrm{N}$, Han Q, Lu Y, Bulterys M, Hutin Y. Estimating the proportion of people with chronic hepatitis $B$ virus infection eligible for hepatitis $B$ antiviral treatment worldwide: a systematic review and metaanalysis. Lancet Gastroenterol Hepatol. 2021;6:106-119.

5. Madihi S, Syed H, Lazar F, Zyad A, Benani A. A systematic review of the current hepatitis $b$ viral infection and hepatocellular carcinoma situation in mediterranean countries. BioMed Res Int. 2020;7027169.

6. Rantala M, van der Laar MJ. Surveillance and epidemiology of hepatitis B and C in Europe. Euro Surveill. 2008;13:18880.

7. Hua W, Zhang G, Guoc S, Li W, Sun L, Xiang G. Microarray-based genotyping and detection of drug-resistant HBV mutations from 620 Chinese patients with chronic HBV infection. Braz J Infect Dis. 2015; 19:291-295.
8. Boesecke C, Wasmuth JC. Distribution and clinical significance of hepatitis B virus genotypes in Pakistan. J Bio Med Cent Gastroenterol. 2012;6:32-35.

9. He X, Wang F, Huang B, Chen P, Zhong L. Detection and analysis of resistance mutations of hepatitis B virus. Int J Clin Exp Med. 2015:8:9630-9639.

10. Bonino F; Hepatitis B virus heterogeneity--a means to personalized care' steering committee. Introduction to 'hepatitis $B$ virus heterogeneity- a means to personalized care'. Antivir Ther. 2010;15(Suppl3):1-2.

11. Salpini R, Alteri C, Cento V, Pollicita M, Micheli V, Gubertini G, Visca M, Romano S, Sarrecchia C. Snapshot on drug-resistance rate and profiles in patients with chronic hepatitis $B$ receiving nucleos $(\mathrm{t})$ ide analogues in clinical practice. J Med Virol. 2013;85:996-1004.

12. Torresi J, Civitico G, Walters T, Lewin SR, Fyfe J. Restoration of replication phenotype of lamivudine resistant hepatitis B virus mutants by compensatory changes in the "fingers" subdomain of the viral polymerase selected as a consequence of mutations in the overlapping S gene. Virology. 2002;299:88-99.

13. Lapiński TW, Pogorzelska J, Flisiak R. HBV mutations and their clinical significance. J Adv Med Sci. 2012;57:18-22.

14. Lok AS, Zoulim F, Locarnini S, Bartholomeusz A, Ghany MG, Pawlotsky JM, Liaw YF, Kuiken C; Hepatitis B Virus Drug Resistance Working Group. Antiviral drug-resistant HBV: standardization of nomenclature and assays and recommendations for management. Int J Hepatol. 2007;46:254-265.

15. Mahmood M, Anwer MA, Khanum A, Zaman N, Raza A. analysis of complete and partial genome sequences of hepatitis $B$ virus and determination of its genotypes and sub-genotypes from Pakistan. Pak J Zool. 2016;48:747-753.

16. Mahmood M, Anwar MA. Analysis of resistant mutations in reverse transcriptase domain of hepatitis B virus from patients from Islamabad Pakistan. J Unexplored Medical Data. 2017;2:60-64.

17. Marhoon AA, Altaai MI, Ahmed AM. Drug-Resistance Associated Mutations in Polymerase (Pol) Gene of Hepatitis B Virus Isolated from Iraqi Chronic Hepatitis B patients (CHB). J Pharm Sci Res. 2018;10:1041-1044

18. Delaney WE 4th, Yang H, Westland CE, Das K, Arnold E, Gibbs CS, Miller MD, Xiong S. The hepatitis $B$ virus polymerase mutation rtV173L is selected during lamivudine therapy and enhances viral replication in vitro. J Virol. 2003;77:11833-11841.

19. Tenney DJ, Levine SM, Rose RE, Walsh AW, Weinheimer SP, Discotto L, Plym M, Pokornowski K, Yu CF, Angus P, Ayres A, Bartholomeusz A, Sievert W, Thompson G, Warner N, Locarnini S, Colonno RJ. Clinical Emergence of Entecavir-Resistant Hepatitis B Virus Requires Additional Substitutions in Virus Already Resistant to Lamivudine. Antimicrob Agents Chemother. 2004;48:3498-3507.

20. Pai SB, Bozdayi AM, Pai RB, Beker T, Sarioglu M, Turkyilmaz AR, Grier J, Yurdaydin C, Schinazi RF. Emergence of a novel mutation in the FLLA Region of hepatitis B virus during lamivudine therapy. Antimicrob Agents Chemother. 2005;49:2618-2624

21. Marrone A, Zampino R, Karayannis P, Cirillo G, Cesaro G, Guerrera B, Ricciotti R, Giudice EMD, Utili R, Adinolfi LE, Ruggiero G. Clinical reactivation during lamivudine treatment correlates with mutations in the precore/core promoter and polymerase regions of hepatitis $B$ virus in patients with anti-hepatitis B e-positive chronic hepatitis. Aliment Pharmacol Ther. 2005;22:707-714

22. Brunelle MN, Jacquard AC, Pichoud C, Durantel D, Durantel SC Villeneuve JP, Tr'epo C, Zoulim F. Susceptibility to antivirals of a human hbv strain with mutations conferring resistance to both lamivudine and adefovir. Hepatology. 2005;41:1391-1398.

23. Sheldon J, Camino N, Rodés B, Bartholomeusz A, Kuiper $M$, Tacke F, Núñez M, Mauss S, Lutz T, Klausen G, Locarnini $S$, Soriano V. Selection of hepatitis B virus polymerase mutations 
in HIV-coinfected patients treated with tenofovir. Antivir Ther. 2005; 10:727-734.

24. Colonno RJ, Rose R, Baldick CJ, Levine S, Pokornowski K, Yu CF, Walsh A, Fang J, Hsu M, Mazzucco C, Eggers B, Zhang S, Plym M, Klesczewski K, Tenney DJ. Entecavir resistance is rare in nucleoside naïve patients with hepatitis B. Hepatology. 2006;44:1656-1665.

25. Warner N, Locarnini S, Kuiper M, Bartholomeusz A, Ayres A, Yuen $L$ Shaw $T$. The L80l substitution in the reverse transcriptase domain of the hepatitis B virus polymerase is associated with lamivudine resistance and enhanced viral replication in vitro. Am Soc Microbiol. 2007; 51:2285-2292.

26. Libbrecht E, Doutreloigne J, Velde HVD, Yuen MF, Lai CL, Shapiro F, Sablon E. Evolution of Primary and Compensatory Lamivudine Resistance Mutations in Chronic Hepatitis B Virus-Infected Patients during Long-Term Lamivudine Treatment, Assessed by a Line Probe Assay. J Clin Microbiol. 2007;45:3935-3941.

27. Malmström S, Hannoun C, Lindh M. Mutation analysis of lamivudine resistant hepatitis B virus strains by TaqMan PCR. J Virol Methods. 2007; 143:147-152.

28. Cassino L, Benetti S, Fay F, Tanno H, Quarleri J. Unsuccessful therapy with adefovir entecavir and tenofovir in a patient with chronic hepatitis B infection with previous resistance to lamivudine: a fourteen-year evolution of hepatitis B virus mutations. Infect Dis. 2011;11:178-184.

29. Zheng J, Zeng Z, Zhang D, Yu Y, Wang F, Pan CQ. Prevalence and significance of Hepatitis $B$ reverse transcriptase mutants in different disease stages of untreated patients. Liver Int. 2012;32:1535-1542.

30. Oin B, Pei RJ, He TT, Huang ZH, Pan GS, Tu CY, Lu M, Chen $\mathrm{XW}$. Polymerase mutations rtN238R, rtT240Y and rtN248H of hepatitis B virus decrease susceptibility to adefovir. Chin Sci Bull. 2013;58:1760-1766.

31. Yin $F$, Xie $Y$, Fan $H$, Zhang J, Guo Z. Mutations in hepatitis B virus polymerase are associated with the postoperative survival of hepatocellular carcinoma patients. PLoS One. 2017;12:e0189730.

32. Lei J, Wang Y, Wang L, Zhang SJ, Chen W, Bai ZG, Xu L. Profile of hepatitis $B$ virus resistance mutations against nucleoside/nucleotide analogue treatment in Chinese patients with chronic hepatitis B. Virol J. 2013;10:313-317.

33. Jiang $S$, Yao L, Hu A, Hu Y, Chen S, Xiong T, Gao G, Liang X, Ding $S$, Weng $P$. Resistant mutants induced by adefovir dipivoxil in hepatitis B virus isolates. World J Gastroenterol. 2014;20:17100-17106.

34. Kim S, Lee J, Ryu WS. Four Conserved Cysteine Residues of the Hepatitis B Virus Polymerase Are Critical for RNA Pregenome Encapsidation. J Virol. 2009;83:8032-8040.
35. Zhao Y, Wu J, Sun L, Liu G, Li B, Zheng Y, Li X, Tao J. Prevalence of mutations in HBV DNA polymerase gene associated with nucleos(t) ide resistance in treatment-naive patients with Chronic Hepatitis B in Central China. Braz J Infect Dis. 2016;20:173-178.

36. Hamidi-Fard M, Makvandi M, Samarbaf-Zadeh A, Hajiani E, Shayesteh A, Masjedizadeh A. Mutation analysis of hepatitis B virus reverse transcriptase region among untreated chronically infected patients in Ahvaz city (South-West of Iran). Indian J Med Microbiol. 2013;31:360-365.

37. Qian F, Qin J, Li D, Ma Z, Zhang H, Jin F, Wang W. Monitoring of genotypic resistance profile in chronic hepatitis $B$ patients receiving nucleos(t)ide analogues in Huzhou, China. J Infect Dev Ctries. 2016;10:996-1002.

38. Zhang $X$, Li M, Xi H, Zhang R, Chen J, Zhang $Y, X u X$. Pre-existing mutations related to tenofovir in chronic hepatitis $B$ patients with long-term nucleos(t)ide analogue drugs treatment by ultra-deep pyrosequencing. Oncotarget. 2016;7:70264-70276.

39. Jiang D, Wang J, Zhao X, Li Y, Zhang $Q$, Song C, Zeng H, Wang $X$. Entecavir resistance mutations rtL180M/T184L/M204V combined with rtA200V lead to tenofovir resistance. Liver Int. 2019;40:83-91.

40. Zhang X, Chen X, Wei M, Zhang C, Xu T, Liu L, Xu Z. Potential resistant mutations within HBV reverse transcriptase sequences in nucleos(t)ide analogues-experienced patients with hepatitis B virus infection. Sci Rep. 2019;9:8078.

41. Hong-Tao C, Gui-Rong H, Zhi Y, Run-zhang M, Shi-Pin W. Investigation into drug-resistant mutations in the treatment of chronic hepatitis B with nucleos(t)ide analogues. Emerg Infect Dis. 2019;4:24-27.

42. Park E, Lee AR, Kim DH, Lee J, Yoo J, Ahn SH, Sim H, Park S, Kang HS, Won J, Ha YN, Shin G, Kwon SY, Park YK, Choi B, Lee YB, Jeong N, An Y, Ju YS, Yu SJ, Chae HB, Yu K, Kim YJ, Yoon J, Zoulim F, Kim K. Identification of a quadruple mutation that confers tenofovir resistance in chronic hepatitis B patients. J Hepatol. 2019;70:1093-1102.

43. Fan J, Zhang $Y$, Xiong $H$, Wang $Y$, Guo $X$. Nucleotide analogueresistant mutations in hepatitis $B$ viral genomes found in hepatitis B patients. J Gen Virol. 2015;96:663-670.

44. Arikan A, Sayan M, Sanlidag T, Suer K, Akcali S, Guvenir M. Evaluation of the pol/S gene Overlapping mutations in chronic hepatitis $b$ patients in Northern Cyprus. Pol J Microbiol. 2019;68:317-322. 